\title{
ANIMAL RESEARCH PAPER Grazing behaviour, herbage intake and animal performance of beef cattle heifers on marandu palisade grass subjected to intensities of continuous stocking management
}

\author{
S. C. DA SILVA ${ }^{*}$, F. M. A. GIMENES ${ }^{2}$, D. O. L. SARMENTO ${ }^{3}$, A. F. SBRISSIA ${ }^{4}$, D. E. OLIVEIRA ${ }^{5}$, \\ A. HERNADEZ-GARAY ${ }^{6}$ AND A. V. PIRES ${ }^{1}$ \\ ${ }^{1}$ USP/ESALQ - Depto. de Zootecnia, C.P. 09-13418-900, Piracicaba, SP, Brazil \\ ${ }^{2}$ Instituto de Zootecnia, Nova Odessa, SP, Brazil \\ ${ }^{3}$ União Pioneira de Integração Social, Animal Science and Veterinary Medicine Faculty, Brasília, DF, Brazil \\ ${ }^{4}$ UDESC/CAV - Lages, SC, Brazil \\ ${ }^{5}$ UDESC - Chapecó, SC, Brazil \\ ${ }^{6}$ Colegio de Postgraduados - Montecillo, Texcoco, Estado de Mexico, Mexico
}

(Received 26 April 2012; revised 10 October 2012; accepted 10 October 2012; first published online 15 November 2012)

\section{SUMMARY}

The ability to adapt to a range of edaphic conditions favours the widespread use of marandu palisade grass in high as well as low input systems of animal production in Brazil. However, little information exists regarding the influence of grazing management practices on sward structure and the carry-over effects on animal responses. The present experiment was planned to evaluate animal behaviour, herbage intake $(\mathrm{HI})$ and nutritive value, herbage accumulation and body weight gain (BWG) of beef cattle heifers grazing marandu palisade grass subjected to intensities of continuous stocking management. Treatments corresponded to four sward surface heights (SSH: 100, 200, 300 and $400 \mathrm{~mm}$ ) and were allocated to experimental units (1200 $\mathrm{m}^{2}$ paddocks) according to a randomized complete block design with four replications. Herbage accumulation rate (HAR) varied with season of the year and $\mathrm{SSH}$, with highest and lowest values recorded during summer and winter, respectively. During the summer, herbage accumulation was larger on swards managed at 200, 300 and $400 \mathrm{~mm}$, with the opposite occurring during winter/ early spring. Stocking rate (SR) and number of grazing days (GD) followed a similar seasonal pattern of variation, with values decreasing as SSH increased. Crude protein (CP) and in vitro organic matter digestibility (IVOMD) of hand-plucked herbage decreased as SSH increased from 100 to $400 \mathrm{~mm}$, while the inverse happened with BWG (from 0.190 to $0.930 \mathrm{~kg} /$ day, respectively). Bite mass (BM) increased and rate of biting and grazing time (GT) decreased as SSH increased, with daily HI being larger on tall (300 and $400 \mathrm{~mm}$ ) relative to short (100 and $200 \mathrm{~mm}$ ) swards. Grazing management affected the nutritive value and the amount of herbage consumed, particularly through changes in BM. However, variations in intake were relatively more important than variations in nutritive value in influencing animal performance, highlighting the importance of providing favourable harvest conditions for grazing animals by establishing adequate sward targets for management.

\section{INTRODUCTION}

Forage plants in pastures are considered the main food source for domestic ruminant animals worldwide. Approximately half of the world beef production comes from tropical and subtropical areas of the

* To whom all correspondence should be addressed. Email: siladasilva@usp.br globe, which has shown an increase in beef and veal production of c. $200 \%$ during the last 40 years (Jank et al. 2005). In Brazil, the scenario is similar, with livestock production being mainly based on grassland use. Globally, Brazil has the largest commercial bovine herd, 172 million head, spread over 160 million hectares of grassland $(0 \cdot 36$ native and 0.64 cultivated) (IBGE 2009), with 0.97 of animals fed 
exclusively on pastures. From 1970 to 1996 , the area of native pastures decreased from 103 to 78 million ha, while that of cultivated pastures increased from 30 to 100 million ha (Jank et al. 2005), indicating a rapid change towards the use of cultivated grasslands, with more than 0.60 of the total grassland area being occupied with cultivated pastures. Among these, the majority of cultivated species belong to the Brachiaria and Panicum genera and, in spite of no official statistics, it is believed that most of the Brachiaria area is occupied with marandu palisade grass (Brachiaria brizantha (Hochst. ex A. Rich) cvar Marandu), since during the 1990s, it represented c. 0.70 of all forage seed sold in Brazil (Andrade 2001).

Traditionally, animal production from pastures in tropical areas has consistently been related to low levels of animal performance, with productivity being $<0 \cdot 05$ and $0 \cdot 10$ of the theoretical potential for milk and meat production, respectively (Da Silva \& Carvalho 2005), as a consequence of poor grazing management practices (Mesquita et al. 2010). In general, pastures show a strong seasonality of production, resulting in large fluctuations in quantity and quality of available herbage, constraining animal production. According to Hodgson et al. (1994), animal productivity depends not only on seasonal variation in herbage yield and nutritive value but also on how grazing management affects sward structure and, consequently, ingestive behaviour, herbage intake $(\mathrm{HI})$ and animal performance. Although herbage quality of tropical grasses is assumed to be inferior relative to temperate grasses, animal production per unit area can be larger due to faster rates of herbage growth and accumulation, provided that harvest of the produced herbage is efficient and carried out within the limits defined by adequate sward targets for grazing management (Da Silva \& Carvalho 2005). Under those circumstances, targets should be decided based on knowledge of how plants respond to variations in sward structure (Hodgson 1985), and management practices considered as a means of generating and/or maintaining those conditions (Hodgson \& Da Silva 2002). These concepts are well developed for temperate grass pastures, but little has been done for tropical species. Against that background, the present experiment was designed to study the influence of contrasting sward conditions defined in terms of height on animal behaviour, $\mathrm{HI}$, nutritive value and body weight gain (BWG) of beef cattle heifers grazing continuously stocked marandu palisade grass.

\section{MATERIALS AND METHODS}

Experimental site, treatments and design

The experiment was carried out at E.S.A. 'Luiz de Queiroz' (ESALQ), University of São Paulo, Piracicaba, SP, Brazil $\left(22^{\circ} 42^{\prime} \mathrm{S}, 47^{\circ} 37^{\prime} \mathrm{W}\right.$ and $550 \mathrm{~m}$ asl) on a marandu palisade grass pasture $(B$. brizantha (Hochst. ex A. Rich) cvar Marandu) established in 2001 on a Eutric Kandiudalf. Average soil chemical characteristics (van Raij et al. 1986) for the 0-200 mm layer were: $\mathrm{pH} \mathrm{CaCl}_{2}$ : 5.6; organic matter $(\mathrm{OM})=41$ $\mathrm{dg} / \mathrm{dm}^{3}$; phosphorus ( $\mathrm{P}$ : ion-exchange resin extraction method $)=67 \mathrm{mg} / \mathrm{dm}^{3}$; calcium $(\mathrm{Ca})=74 \mathrm{mmol}_{\mathrm{c}} / \mathrm{dm}^{3}$; magnesium $(\mathrm{Mg})=19 \mathrm{mmol}_{\mathrm{C}} / \mathrm{dm}^{3} ;$ potassium $(\mathrm{K})=6.5$ $\mathrm{mmol}_{\mathrm{C}} / \mathrm{dm}^{3}$; hydrogen $(\mathrm{H})+$ aluminium $\quad(\mathrm{Al})=36$ $\mathrm{mmol}_{\mathrm{C}} / \mathrm{dm}^{3}$; sum of bases $=99 \mathrm{mmol}_{\mathrm{C}} / \mathrm{dm}^{3}$; cation exchange capacity $=134.8 \quad \mathrm{mmol}_{\mathrm{c}} / \mathrm{dm}^{3}$; base saturation $=74 \%$. According to the Köppen classification, the climate is Cwa (sub-tropical with dry winter). Rainfall, solar radiation and daylight hours, average mean, minimum and maximum air temperatures, and soil water balance (Thornthwaite \& Mather 1955) are shown in Figs 1-3, respectively, and indicate an average year considering historical data (1917-2002). Swards were fertilized with nitrogen (N) and $\mathrm{K}$ throughout the experimental period (Table 1 ).

Treatments corresponded to four sward surface heights (SSH: 100, 200, 300 and $400 \mathrm{~mm}$ ) generated by continuous stocking and maintained on target using variable stocking rate (SR). These were allocated to experimental units ( $1200 \mathrm{~m}^{2}$ paddocks) according to a randomized complete block design with four replications. The paddocks were grazed by a 2-year old Nelore (Bos taurus indicus) and Canchim (5/8 Charolais (Bos taurus taurus) $\times 3 / 8$ Zebu (Bos taurus indicus)) heifers with an average initial body weight (BW) of $280 \mathrm{~kg}$. The experimental period started on 8 January 2002 and finished on 14 February 2003, totalling 380 days.

Prior to the beginning of measurements, on 28 and 29 August 2001, paddocks were grazed and subsequently mowed to c. $80 \mathrm{~mm}$ in preparation for the experiment. From then onwards, $\mathrm{SSH}$ was monitored on a weekly basis and animals introduced to paddocks as swards approached target heights. Once grazing started, monitoring of sward height was performed twice a week ( 3 and 4 day intervals) on 20 points per paddock using a thin acetate sheet and ruler (Fagundes et al. 1999). Average sward height on paddocks was allowed to vary by $10 \%$ around the target, with animals being added or removed when the upper or 


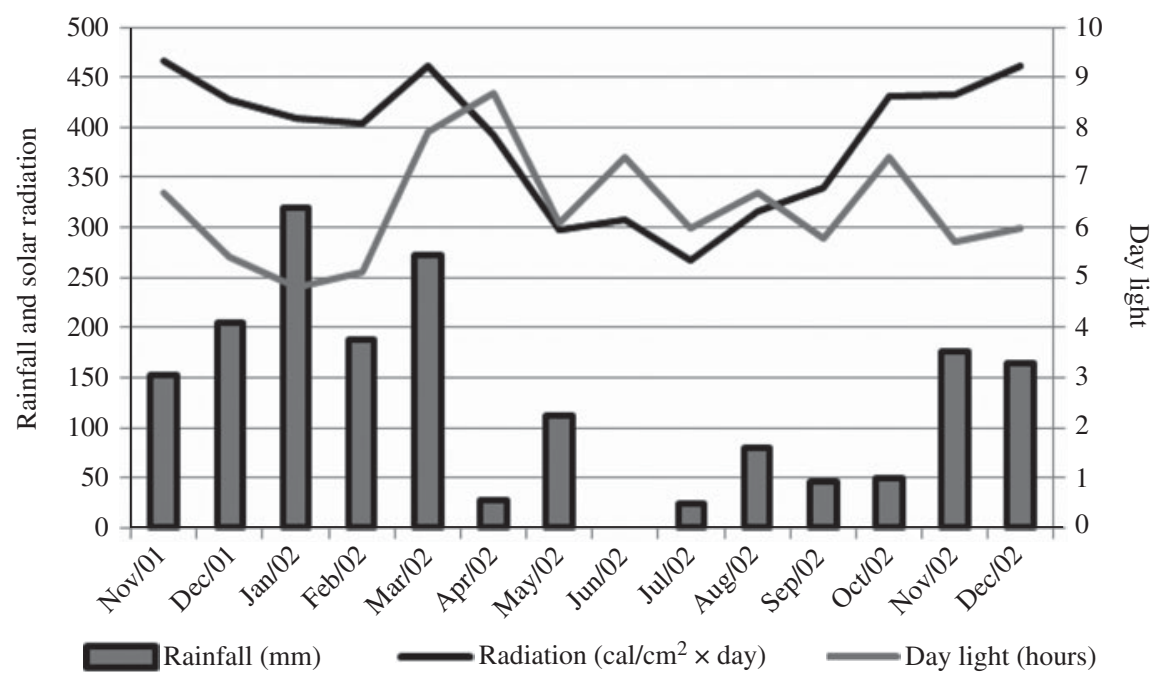

Fig. 1. Monthly rainfall, solar radiation and day light hours on the experimental site from November 2001 to December 2002.

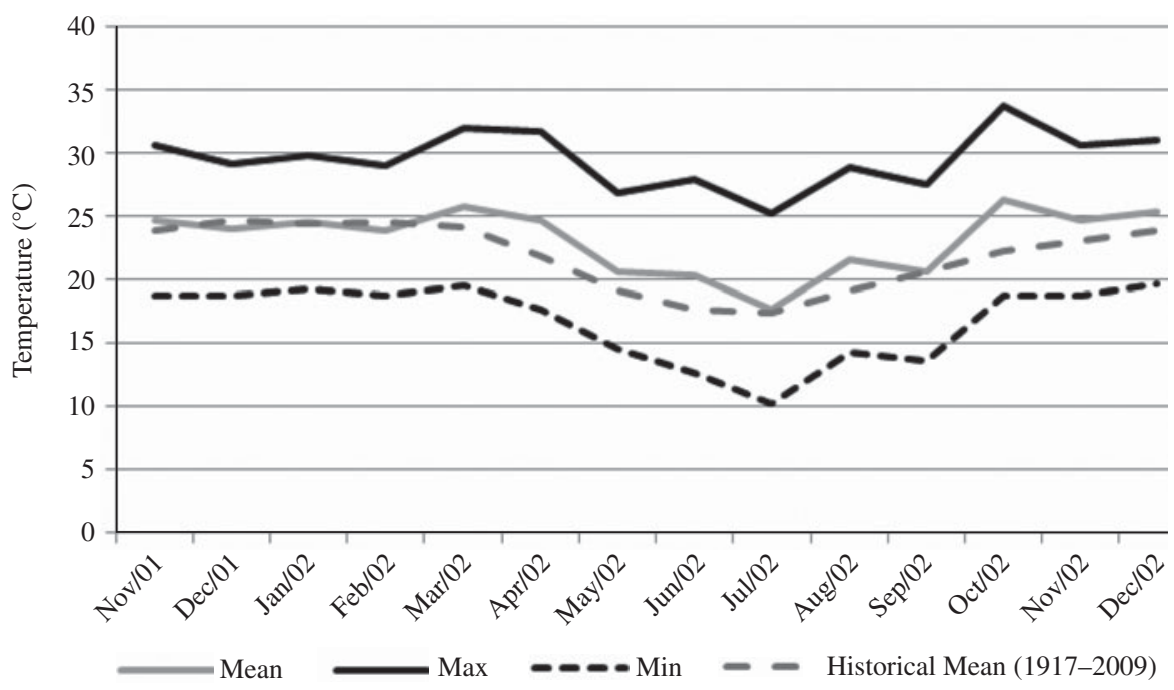

Fig. 2. Average mean, minimum and maximum air temperature on the experimental site from November 2001 to December 2002.

lower limit of the range, respectively, was close to being reached (Fig. 4). All paddocks had animals grazing at the end of October 2001, ensuring a minimum period of 60 days under the grazing regimes imposed until the commencement of measurements in 8 January 2002.

\section{Measurements}

\section{Herbage accumulation}

Herbage accumulation was measured using four $1 \cdot 4 \times 0 \cdot 7 \mathrm{~m}$ exclosure cages $\left(1 \cdot 0 \mathrm{~m}^{2}\right)$ per paddock, which were rotated every 3 weeks. After each sampling, cages were rotated and anchored on new areas representative of sward conditions (visual assessment of herbage mass and height). Herbage accumulation was calculated as the difference between the herbage mass under the cage at the last and the first day of exclusion (Davies et al. 1993). These were determined using calibration curves between sward height and herbage mass produced in a concomitant set of measurements being made in the same experimental area using a similar procedure described by Braga et al. (2009). 


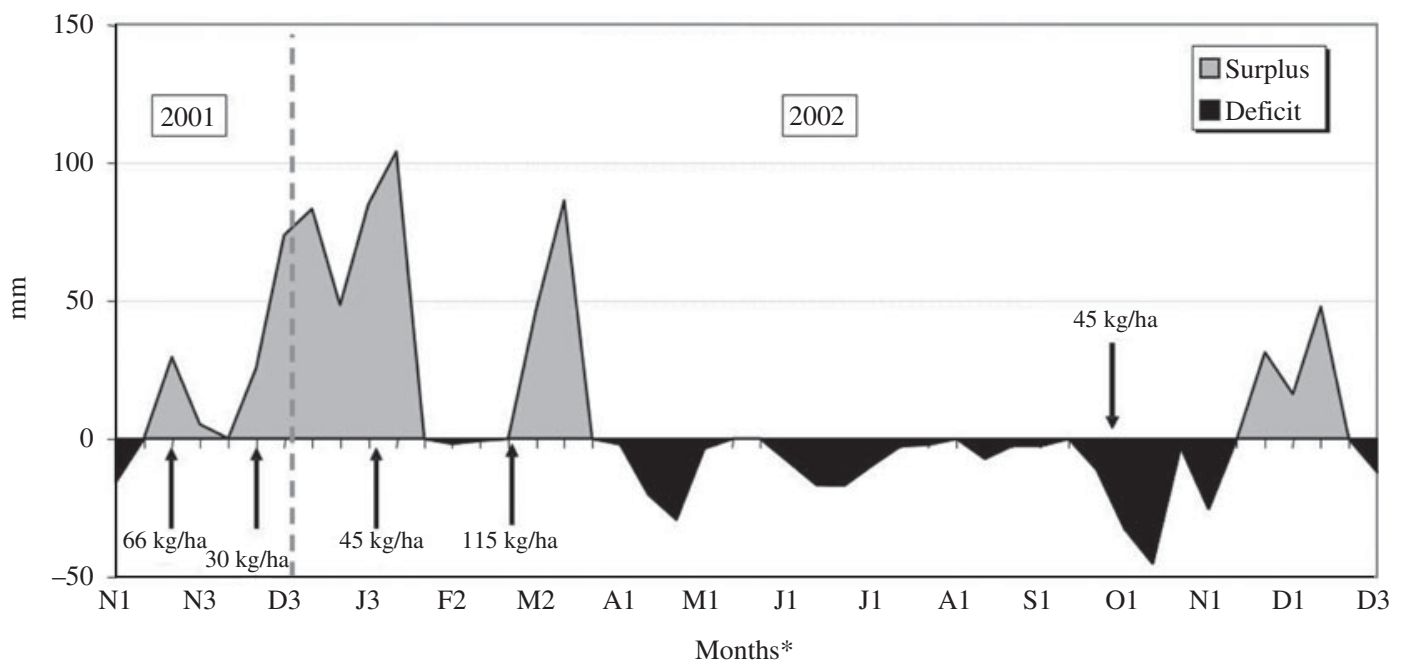

Fig. 3. Monthly soil water balance (calculated at 10 day intervals considering a soil water storage capacity of $50 \mathrm{~mm}$ ) from November 2001 to December 2002 (arrows correspond to $\mathrm{N}$ application dates and rates).

Morphological composition and nutritive value of the herbage produced

A grazing simulation method was used to collect herbage samples for chemical analysis and digestibility determination (Sollenberger \& Cherney 1995). A random sample of $500 \mathrm{~g}$ was harvested by hand per paddock every month, placed in plastic bags and stored in a cool room. A subsample was then used to determine botanical (marandu palisade grass and other species) and morphological (leaf (lamina), stem (sheaths + stem) and dead material) composition. The remaining material was dried in a forced draught oven at $65{ }^{\circ} \mathrm{C}$ to constant weight. After drying, subsamples were ground using a Wiley Mill with a $1 \mathrm{~mm}$ sieve and stored at room temperature for chemical analysis.

$\mathrm{CP}$ was determined using the volumetric method of micro Kjeldhal (AOAC 1990) and neutral detergent fibre (NDF) and acid detergent fibre (ADF) determined according to Van Soest et al. (1991), adapted for the ANKOM 200 methodology (ANKOM 200 Fibre Analyzer, ANKOM Technology Corporation, Fairport, NY, USA). Determination of in vitro organic matter digestibility (IVOMD) was made as proposed by Holden (1999) using a Daisy Incubator II (ANKOM Technology Corp.).

\section{Live weight gain, SR and grazing days}

Measurements of animal performance were made using two test animals per experimental unit (paddock) and a variable number of extra heifers used to adjust SR and allow experimental conditions to be maintained according to the treatment specifications. Animals (test and variable stock) were weighed immediately before entering or exiting paddocks, and adjustments in SR carried out twice a week using animal's shrunk weight (12 h). Owing to the size of the paddocks relative to the BW of animals, there were times that test animals remained for less than a week or had to be away from paddocks during long periods, particularly during autumn, winter and early spring (April-November). In such cases, animals were removed from experimental units, put to graze on an adjacent area composed of the same grass species and the number of days without grazing being recorded. For that reason, measurements of daily weight gain were performed only during late spring and summer (December 2001-March 2002), the period of active and fast plant growth.

Animal behaviour, bite mass (BM) and bite rate (BR)

Measurements of animal behaviour were performed during $24 \mathrm{~h}$ periods in January, February, May, July, August and December 2002, with observations and identification of animals at 10 min intervals using binoculars and stop watches. For night observations, flash lights were used, with animals being habituated with the procedure at least 1 month beforehand. To facilitate identification, one of the two animals in each paddock was marked with automotive spray. A total of eight animals per treatment was originally planned (four replications - blocks - and two test animals per replication), but when pasture growth was low and not all paddocks could support animals (need to maintain targets of sward height), there was always a minimum 
Table 1. Dates and rates of fertilizer application throughout the experimental period

\begin{tabular}{lcll}
\hline \hline Date & $\begin{array}{l}\text { Rate of } \mathrm{N} \\
\text { application }(\mathrm{kg} / \mathrm{ha})\end{array}$ & $\begin{array}{l}\text { Rate of } \mathrm{K} \\
\text { application }(\mathrm{kg} / \mathrm{ha})\end{array}$ & Fertilizer \\
\hline 7 Nov 2001 & 66 & - & Ammonium nitrate \\
1 Dec 2001 & 30 & 17 & $30: 00: 20^{*}$ \\
10 Jan 2002 & 45 & 25 & $30: 00: 20$ \\
7 Mar 2002 & 115 & - & Urea \\
30 Oct 2002 & 45 & - & Urea \\
Total & 301 & 42 & \\
\hline
\end{tabular}

* Commercial N:P:K formula.

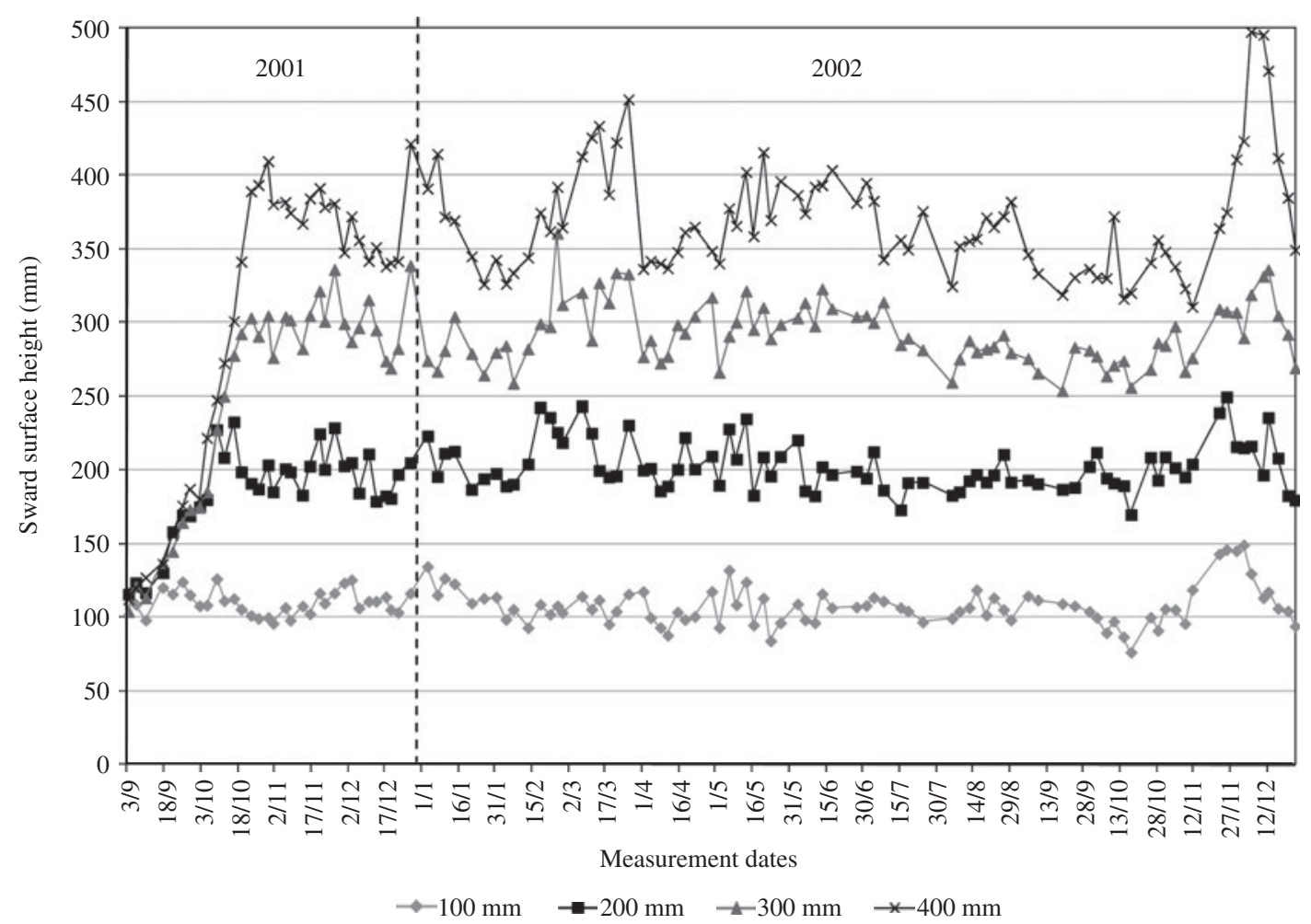

Fig. 4. Average SSH of experimental treatments from 3 September 2001 to 17 December 2002. Vertical line indicates the start of the experiment.

of four animals per treatment. Measurements were carried out by a group of eight pre-trained observers allocated to blocks in pairs. At the end of each measurement period, observations of activities for each animal were combined and the time spent grazing, ruminating and with other activities throughout the day calculated accordingly.

During the $24 \mathrm{~h}$ periods of animal behaviour observations, animals were filmed during periods of intense grazing activity (early in the morning and late in the afternoon) from the top of two observation towers. Several tapes $(10 \mathrm{~min})$ were recorded for each animal with the objective of generating the largest possible number of images from animals within each paddock. From the tapes, the time spent for executing 20 bites was determined and the results used to calculate BR (Hodgson 1982).

Measurements of BM were made using oesophageal fistulated Nelore (Bos taurus indicus) heifers. Only two evaluations were carried out because fistulated animals had to be operated and trained to be used. The first measurement period was from 31 August to 5 September 2002, and the second from 10 to 14 February 2003. Four fistulated animals were used in pairs, one pair for each two blocks, early in the morning and late in the afternoon, times of more 
Table 2. Rates of herbage accumulation ( \pm S.E.M.) on marandu palisade grass subjected to intensities of continuous stocking management from January to December 2002

\begin{tabular}{|c|c|c|c|c|c|}
\hline \multirow[b]{3}{*}{ Season of the year* } & \multicolumn{4}{|c|}{ Sward height (mm) } & \multirow[b]{3}{*}{ Mean } \\
\hline & 100 & 200 & 300 & 400 & \\
\hline & \multicolumn{4}{|c|}{ (kg/ha/day of DM) } & \\
\hline Summer & $117(6 \cdot 7)$ & $144(6 \cdot 3)$ & $134(6 \cdot 3)$ & $135(5 \cdot 9)$ & $133(3 \cdot 3)$ \\
\hline Autumn & $61(7 \cdot 8)$ & $62(7 \cdot 4)$ & $44(7 \cdot 4)$ & $18(7 \cdot 4)$ & $46(3 \cdot 2)$ \\
\hline Winter-early spring & $22(6 \cdot 0)$ & $10(6 \cdot 3)$ & $-2(6 \cdot 0)$ & $-23(6 \cdot 3)$ & $2(3 \cdot 2)$ \\
\hline Late spring & $84(10 \cdot 1)$ & $89(10 \cdot 2)$ & $133(10 \cdot 1)$ & $142(11 \cdot 7)$ & $112(3 \cdot 5)$ \\
\hline
\end{tabular}

* Summer (Dec-Mar), Autumn (Apr-Jun), Winter-early spring (Jul-Oct), and Late spring (Nov-Dec).

intense grazing activity. For each measurement procedure, animals were equipped with collection bags and allowed to graze for 15 min during which the number of bites taken was counted. At the end of measurement, the collection bags were removed and extrusa samples immediately placed into plastic bags, quantified, subsampled and sent for drying in a forced draught oven at $65^{\circ} \mathrm{C}$ to constant weight. The results were used to calculate BM.

\section{$H I$}

Intake measurements were made using controlled release capsules (CRC) containing $8 \mathrm{~g}$ of $\mathrm{n}$-dotriacontane (C32) and $8 \mathrm{~g}$ of n-hexatriacontane (C36) (Captec, New Zealand) to estimate HI (Burns et al. 1994). Two estimates of intake were made. The first was carried out on 14 January 2002, using 27 Nelore heifers with an average BW of $280 \mathrm{~kg}$. These received the CRCs after a 16-h fast period and were placed into their paddocks where they remained until the end of the measurement period. This corresponded to an 8-day interval for stabilization of n-alkanes release and another 5-day interval for faecal sampling. There was the possibility of using 32 capsules (four treatments $\times$ four replications $\times$ two animals per replication), but, because of anatomical limitations of some animals relative to the CRC size, only 27 could receive them. Faecal samples were harvested every day at $07.00 \mathrm{~h}$ and frozen. Later, they were dried in a forced draught oven at $65^{\circ} \mathrm{C}$ until constant weight, ground and pooled across days to form one composite sample per animal. The second estimate of $\mathrm{HI}$ was made on 11 December 2002 using 30 Nelore heifers with an average BW of $240 \mathrm{~kg}$ following the same procedure described above, the only difference being that the period of faecal sampling lasted 7 days instead of 5 .
During both periods of $\mathrm{HI}$ measurement, random herbage samples of simulated grazing were harvested using the hand plucking procedure (c. $300 \mathrm{~g}$ fresh weight). These were separated into two subsamples and one used for the separation of the morphological components leaf (leaf laminae) and stem (leaf sheath + stem). Both subsamples were dried in a forced draught oven at $65{ }^{\circ} \mathrm{C}$ to constant weight and ground for $\mathrm{n}$ alkane profile analysis. Extraction and calculation procedures for $n$-alkanes followed those described by Oliveira et al. (2007), and the results used to calculate HI.

\section{Statistical analysis}

Analysis of variance of the data was carried out using the Mixed Procedure of SAS ${ }^{\circledR}$. The choice of the covariance matrix was made using the Akaike Information Criterion (AIC) (Wolfinger 1993), and analysis performed considering $\mathrm{SSH}$, season of the year and their interaction as fixed effects and blocks as a random effect (Littel et al. 2000). When appropriate, treatment means were calculated using the 'LSMEANS' statement, and comparisons made using Student $t$ test and $P \leqslant 0 \cdot 05$.

\section{RESULTS}

Herbage accumulation

Herbage accumulation rates (HARs) were not influenced by $\mathrm{SSH}$, but varied with season of the year $(P<0.001)$ and with the $\mathrm{SSH} \times$ season of the year interaction $(P<0 \cdot 001)$. The highest and lowest values of HAR were recorded during summer $(132 \cdot 6 \mathrm{~kg} / \mathrm{ha} /$ day $)$ and winter-early spring $(1.9 \mathrm{~kg} / \mathrm{ha} /$ day $)$, respectively (Table 2). From winter-early spring to late spring average 
Table 3. $S R^{*}$ of marandu palisade grass ( \pm S.E.M.) subjected to intensities of continuous stocking management from January-December 2002

\begin{tabular}{|c|c|c|c|c|c|}
\hline \multirow[b]{3}{*}{ Season of the yeart } & \multicolumn{4}{|c|}{ Sward height (mm) } & \multirow[b]{3}{*}{ Mean } \\
\hline & 100 & 200 & 300 & 400 & \\
\hline & \multicolumn{4}{|l|}{ (AU/ha) } & \\
\hline Summer & $8.7(0.16)$ & $5 \cdot 9(0 \cdot 14)$ & $4 \cdot 3(0 \cdot 15)$ & $3 \cdot 0(0 \cdot 14)$ & $5.5(0.07)$ \\
\hline Autumn & $2 \cdot 8(0 \cdot 21)$ & $2 \cdot 3(0 \cdot 18)$ & $1 \cdot 1(0 \cdot 16)$ & $0 \cdot 2(0 \cdot 16)$ & $1 \cdot 6(0 \cdot 09)$ \\
\hline Winter-early spring & $0.0(0.18)$ & $0 \cdot 0(0 \cdot 15)$ & $0 \cdot 0(0 \cdot 14)$ & $0 \cdot 0(0 \cdot 14)$ & $0.0(0.08)$ \\
\hline Late spring & $4.9(0.30)$ & $4 \cdot 1(0 \cdot 24)$ & $3 \cdot 2(0 \cdot 23)$ & $1 \cdot 4(0 \cdot 23)$ & $3 \cdot 4(0 \cdot 13)$ \\
\hline
\end{tabular}

* Calculated as animal units ( $\mathrm{AU}=1$ adult animal weighing $450 \mathrm{~kg})$.

+ Summer (Dec-Mar), Autumn (Apr-Jun), Winter-early spring (Jul-Oct), and Late spring (Nov-Dec).

Table 4. Number of GD on marandu palisade grass ( \pm S.E.M.) subjected to intensities of continuous stocking from December 2001 to December 2002*

\begin{tabular}{|c|c|c|c|c|c|}
\hline \multirow[b]{3}{*}{ Season of the yeart } & \multicolumn{4}{|c|}{ Sward height $(\mathrm{mm})$} & \multirow[b]{3}{*}{ Mean } \\
\hline & 100 & 200 & 300 & 400 & \\
\hline & \multicolumn{4}{|l|}{ (days) } & \\
\hline Summer & $99(2 \cdot 9)$ & $68(2 \cdot 9)$ & $50(2 \cdot 9)$ & $36(2 \cdot 9)$ & $63(1 \cdot 5)$ \\
\hline Autumn & $27(1.9)$ & $17(1.9)$ & $6(1.9)$ & $1(1 \cdot 9)$ & $13(0 \cdot 9)$ \\
\hline Winter-early spring & $17(2 \cdot 4)$ & $3(2 \cdot 4)$ & $1(2 \cdot 4)$ & $0(2 \cdot 4)$ & $5(1 \cdot 2)$ \\
\hline Late spring & $34(1 \cdot 1)$ & $27(1 \cdot 1)$ & $25(1 \cdot 1)$ & $13(1 \cdot 1)$ & $25(0 \cdot 5)$ \\
\hline Total & 178 & 116 & 82 & 51 & \\
\hline
\end{tabular}

* 391 days of experiment.

+ Summer (Dec 2001-Mar 2002), Autumn (Apr-Jun 2002), Winter-early spring (Jul-Oct 2002), and Late spring (Nov-Dec 2002).

HAR increased from 1.9 to $111.8 \mathrm{~kg} /$ ha/day. During summer, the lowest values of HAR were recorded on swards managed at $100 \mathrm{~mm}$, whereas in autumn the lowest values were recorded on those managed at 400 $\mathrm{mm}$. During winter-early spring HAR was lower on swards managed at 300 and $400 \mathrm{~mm}$ than at 100 and $200 \mathrm{~mm}$, with the inverse happening in late spring, when HAR of swards managed at 300 and $400 \mathrm{~mm}$ were higher than those managed at 100 and $200 \mathrm{~mm}$, respectively $(P<0 \cdot 05)$.

SR and number of grazing days

SR varied with $\mathrm{SSH}(P<0 \cdot 001)$, season of the year $(P<0.001)$ and $\mathrm{SSH} \times$ season of the year interaction $(P<0.001)$. With the exception of winter-early spring, recorded values decreased with increasing $\mathrm{SSH}$ and were largest in summer, followed by those in late spring, autumn and winter-early spring (Table 3).

Similarly, the number of grazing day (GD) varied with SSH $(P<0.001)$, season of the year $(P<0.0001)$ and the SSH $\times$ season of the year interaction $(P<0 \cdot 001)$ (Table 4). The number of GD decreased with increasing SSH and was largest in summer, followed by those in late spring, autumn and winter-early spring. Overall, the number of GD corresponded to $0 \cdot 13-0 \cdot 45$ of the experimental period (391 days) for swards managed at 400 and $100 \mathrm{~mm}$, respectively.

Morphological composition of hand plucked herbage samples

Morphological composition of herbage samples harvested using the hand plucking procedure was not affected by either $\mathrm{SSH}$ or $\mathrm{SSH} \times$ season of the year 
Table 5. Morphological composition of hand plucked herbage samples ( \pm S.E.M.) on continuously stocked marandu palisade grass from January to December 2002

\begin{tabular}{lllcl}
\hline \hline \multirow{2}{*}{$\begin{array}{l}\text { Season of the } \\
\text { year* }\end{array}$} & Leaf & Stem & Dead & Weeds \\
\cline { 2 - 5 } & $(\mathrm{g} / \mathrm{kg})$ & & & \\
\hline Summer & $919(7 \cdot 9)$ & $49(2 \cdot 8)$ & $9(1 \cdot 2)$ & $22(2 \cdot 2)$ \\
Autumn & $812(14 \cdot 7)$ & $55(4 \cdot 9)$ & $117(9 \cdot 8)$ & $16(2 \cdot 4)$ \\
$\begin{array}{l}\text { Winter-early } \\
\text { spring }\end{array}$ & $772(14 \cdot 1)$ & $27(3 \cdot 0)$ & $184(12 \cdot 1)$ & $16(1 \cdot 9)$ \\
Late spring & $854(12 \cdot 4)$ & $60(6 \cdot 3)$ & $69(9 \cdot 5)$ & $16(4 \cdot 3)$ \\
\hline \hline
\end{tabular}

* Summer (Dec-Mar), Autumn (Apr-Jun), Winter-early spring (Jul-Oct) and Late spring (Nov-Dec).

interaction, varying only with season of the year $(P<0 \cdot 001)$ (Table 5).

\section{Nutritive value}

There was a clear contrast for all studied variables between swards managed at 100 and $400 \mathrm{~mm}$. CP content and IVOMD decreased as $\mathrm{SSH}$ increased from 100 to $400 \mathrm{~mm}$, the reverse happening with NDF and ADF $(P<0 \cdot 05)($ Table 6).

\section{BWG}

Daily weight gain varied with SSH $(P=0.003)$, with lower values recorded on swards managed at 100 and $200 \mathrm{~mm}(0.190$ and $0.510 \mathrm{~kg} / \mathrm{animal} /$ day, respectively) than on those managed at $400 \mathrm{~mm}(0.930 \mathrm{~kg} /$ animal/day). Swards managed at $300 \mathrm{~mm}(0.750 \mathrm{~kg} /$ animal/day) did not differ from those managed at 200 and $400 \mathrm{~mm}$. Overall, swards managed at higher SSH resulted in greater daily BWG, but lower SR (Table 3), with highest gain/ha recorded at 300 and $400 \mathrm{~mm}$ (263, 514, 569 and $571 \mathrm{~kg} / \mathrm{ha}$ of BWG for swards managed at 100, 200, 300 and $400 \mathrm{~mm}$, respectively).

\section{Grazing behaviour and $\mathrm{HI}$}

\section{$B M$}

BM was influenced only by SSH $(P<0 \cdot 001)$. There was no effect of month of the year nor $\mathrm{SSH} \times$ month of the year interaction. The lowest and highest values were recorded on swards managed at 100 and $400 \mathrm{~mm}$, respectively, with intermediate values on swards managed at 200 and $300 \mathrm{~mm}(0.5,0 \cdot 8,1 \cdot 2$ and
$1 \cdot 5 \pm 0 \cdot 10 \mathrm{~g} /$ bite for $100,200,300$ and $400 \mathrm{~mm}$, respectively).

$B R$

BR was influenced by SSH $(P<0 \cdot 001)$, month of the year $(P<0.001)$ and $\mathrm{SSH} \times$ month of the year interaction $(P<0.001)$ (Table 7). Overall, BR values increased as SSH decreased from 400 to $100 \mathrm{~mm}$, with a minimum of 16.4 bites/min on swards managed at $400 \mathrm{~mm}$ in February and a maximum of $55 \cdot 2$ bites/ min on swards managed at $100 \mathrm{~mm}$ in May.

\section{Grazing time (GT)}

GT was influenced by SSH $(P<0 \cdot 001)$ and month of the year $(P=0 \cdot 002)$. The largest values were recorded on swards managed at $100 \mathrm{~mm}$, with no difference between swards managed at 200, 300 and $400 \mathrm{~mm}$ $(684,642,636$ and $630 \pm 14$ min on swards managed at 100, 200, 300 and $400 \mathrm{~mm}$, respectively). Throughout the year, GT was largest in June and lowest in January, February and August, with intermediate values recorded in May and December (636, 606, 630, 726, 618 and $672 \pm 18$ min for January, February, May, June, August and December, respectively).

\section{HI}

Daily $\mathrm{HI}$ varied with SSH $(P<0.001)$ and month of the year $(P<0 \cdot 001)$, with no significant effect seen for the $\mathrm{SSH} \times$ month of the year interaction. HI was lowest on swards managed at $100 \mathrm{~cm}$, with no difference between those managed at 200, 300 and $400 \mathrm{~mm}$ $(1 \cdot 31,1 \cdot 78,1 \cdot 84$ and $1.96 \mathrm{~kg} / 100 \mathrm{~kg}$ of BW for swards managed at 100, 200, 300 and $400 \mathrm{~mm}$, respectively). Overall, intake values were larger in December relative to January $2002(1.90$ and $1.56 \mathrm{~kg} / 100 \mathrm{~kg}$ $\mathrm{BW}$, respectively).

\section{DISCUSSION}

Animal production from pastures is not uniform throughout the year as a consequence of the variation in environmental factors such as rainfall, solar radiation and temperature. In general, herbage accumulation in the tropics is larger during warm and wet months (October-March) and comprises $0 \cdot 8-0 \cdot 9$ of the annual accumulation, with the remaining $0 \cdot 1-0 \cdot 2$ occurring from April to September (Pedreira \& Mattos 1981). In the current study, climatic 
Table 6. CP, IVOMD, NDF and ADF of hand plucked herbage samples ( \pm S.E.M.) on marandu palisade grass subjected to intensities of continuous stocking management from January-December, 2002

\begin{tabular}{lllll}
\hline \hline Sward height $(\mathrm{mm})$ & CP* $(\mathrm{g} / \mathrm{kg})$ & IVMOD* & NDF* $^{*}(\mathrm{~g} / \mathrm{kg})$ & ADF* $(\mathrm{g} / \mathrm{kg})$ \\
\hline 100 & $137(2 \cdot 5)$ & $0 \cdot 671(0 \cdot 0064)$ & $608(3 \cdot 1)$ & $281(2 \cdot 4)$ \\
200 & $127(2 \cdot 5)$ & $0 \cdot 662(0 \cdot 0067)$ & $618(2 \cdot 9)$ & $288(2 \cdot 3)$ \\
300 & $124(2 \cdot 5)$ & $0 \cdot 631(0 \cdot 0068)$ & $622(2 \cdot 9)$ & $292(2 \cdot 3)$ \\
400 & $113(2 \cdot 5)$ & $0 \cdot 624(0 \cdot 0067)$ & $619(3 \cdot 1)$ & $290(2 \cdot 4)$ \\
\hline \hline
\end{tabular}

* Ash-free calculated values.

Table 7. $B R$ ( \pm S.E.M.) on marandu palisade grass subjected to intensities of continuous stocking from JanuaryDecember 2002

\begin{tabular}{|c|c|c|c|c|c|}
\hline \multirow[b]{3}{*}{ Month } & \multicolumn{4}{|c|}{ Sward height (mm) } & \multirow[b]{3}{*}{ Mean } \\
\hline & 100 & 200 & 300 & 400 & \\
\hline & \multicolumn{4}{|c|}{ (bites/minute) } & \\
\hline January & $40(1 \cdot 4)$ & $30(1 \cdot 4)$ & $23(1 \cdot 4)$ & $17(1 \cdot 4)$ & $28(0 \cdot 7)$ \\
\hline February & $40(1 \cdot 4)$ & $27(1 \cdot 4)$ & $23(1 \cdot 4)$ & $16(1 \cdot 4)$ & $27(0 \cdot 7)$ \\
\hline May & $55(1 \cdot 4)$ & $30(1 \cdot 4)$ & $24(1 \cdot 4)$ & $17(1 \cdot 4)$ & $32(0.7)$ \\
\hline June & $41(1 \cdot 4)$ & $28(1 \cdot 4)$ & $25(1 \cdot 4)$ & $19(1 \cdot 4)$ & $28(0 \cdot 7)$ \\
\hline August & $48(1 \cdot 4)$ & $33(1 \cdot 4)$ & $24(1 \cdot 4)$ & $17(1 \cdot 4)$ & $31(0 \cdot 7)$ \\
\hline December & $53(1 \cdot 4)$ & $33(1 \cdot 4)$ & $24(1 \cdot 4)$ & $18(1 \cdot 4)$ & $32(0 \cdot 7)$ \\
\hline Mean & $46(0 \cdot 6)$ & $30(0 \cdot 6)$ & $24(0 \cdot 6)$ & $18(0 \cdot 6)$ & \\
\hline
\end{tabular}

conditions were close to an average year considering historical data from 1917 to 2002 and rates of herbage accumulation changed according to season of the year and within seasons of the year as a function of $\mathrm{SSH}$. During summer and late spring, when environmental conditions were favourable, rates of herbage accumulation were high, particularly on swards managed at 300 and $400 \mathrm{~mm}$. In this period, light availability was probably the main limiting factor within the sward canopy, and herbage accumulation followed the classical pattern of response described for perennial ryegrass (Bircham \& Hodgson 1983) and Cynodon (Pinto et al. 2001), with similar herbage accumulation on swards managed at 200, 300 and $400 \mathrm{~mm}$. However, during autumn and winter-early spring, times of the year when temperature and rainfall were lower and there was soil water deficit, herbage accumulation decreased as SSH increased from 100 to $400 \mathrm{~mm}$. Taller swards are more likely to be susceptible to water stress, since their evapotranspiration is larger. In addition, leaves in poorly managed swards are generally older and less photosynthetically active (Parsons et al. 1988) and, therefore, unlikely to contribute substantially to plant growth (Gifford \& Marshall 1973; Woledge 1977). Variations in herbage accumulation resulted in variations in SR and number of GD, simply reflecting the way monitoring and control of grazing was carried out during the experiment (e.g. maintenance of SSH targets). Overall, the number of GD during the experiment was low, with animals remaining on paddocks only $0 \cdot 13-0.45$ of the entire experimental period as a consequence of the small size of paddocks $\left(1200 \mathrm{~m}^{2}\right)$ relative to the size of animals (c. $300 \mathrm{~kg}$ ) used in the experiment and the strong, typical seasonality of herbage production.

SR depends not only on the productivity of forage species and the amount of herbage on offer but also on the efficiency with which the produced herbage is harvested by the grazing animal. In the current study, SR and the number of GD showed the same pattern of variation described for herbage accumulation. In general, high values of SR and GD were recorded in summer, followed by those in late spring, autumn and winter-early spring, with values increasing as SSH decreased from 400 to $100 \mathrm{~mm}$. The number of GD is a 
SR-related variable, and may be considered low because it corresponded to a low proportion of the total experimental period ( $0 \cdot 13$ (51 days) to 0.45 (178 days) for the 400 and $100 \mathrm{~mm}$, respectively). Carnevalli et al. $(2001 a, b)$, in an analogous grazing experiment with Cynodon cultivars and grazing sheep, also reported a number of GD smaller than the experimental period $(0.83$ and 0.89 for coastcross and tifton 85 , respectively), but with numbers significantly larger than those recorded in the current study. This may be associated with the smaller size of animals used by Carnevalli et al. $(2001 a, b)$ (sheep and not cattle) and the small paddock size used in the current experiment, but it is certainly a consequence of the need to vary the SR to maintain SSH targets. Although it may result in periods of time with no animals on the paddocks, sward conditions mimic a truly continuous stocking management, since even under continuous stocking individual leaves and tillers are defoliated intermittently (Lemaire et al. 2009).

The chemical composition of the hand-plucked herbage indicated a reduction in nutritive value as $\mathrm{SSH}$ increased, since CP and IVOMD decreased and NDF and ADF increased. However, the differences were not large relative to the recorded differences in daily weight gain, indicating that nutritive value was relatively less important than $\mathrm{HI}$ in determining animal performance (Stobbs 1973; Hodgson 1990; Carvalho et al. 2001; Benvenutti et al. 2006; Euclides et al. 2009). Differences in CP and IVOMD corresponded to $-17 \cdot 5 \% \quad(137-113 \mathrm{~g} / \mathrm{kg})$ and $-7 \cdot 0 \%(671-624 \mathrm{~g} / \mathrm{kg})$ between swards managed at 100 and $400 \mathrm{~mm}$, while differences in $\mathrm{HI}$ and BWG corresponded to around $+50 \%(1 \cdot 31-1 \cdot 96 \mathrm{~kg} / 100 \mathrm{~kg} \mathrm{BW})$ and $+340 \%(0 \cdot 190-$ $0.930 \mathrm{~kg} /$ animal/day), respectively. Hodgson (1990) pointed out that on efficiently grazed continuously stocked swards, animals are consistently eating young leaf material and, as a result, digestibility and CP of the consumed herbage should remain high. However, on swards maintained at a low height the turnover of leaves and tillers is higher than on swards maintained at taller heights (Hernandez-Garay et al. 2000; Sbrissia et al. 2010), a condition that would result in low herbage mass comprised of younger leaves and tissues, explaining the results for CP, IVOMD, NDF and ADF in the current study. Similar results were presented by Flores et al. (2008) for continuously stocked B. brizantha cvar Marandu and Xaraés maintained at 150, 250 and $400 \mathrm{~mm}$ using a similar grazing protocol.
In spite of the higher nutritive value, $\mathrm{HI}$ in the current study was lower on swards managed at $100 \mathrm{~mm}$, mainly because of the reduced BM under those conditions $(0.5$ and $1.5 \mathrm{~g} /$ bite on swards managed at 100 and $400 \mathrm{~mm}$, respectively). Reduction in BM is a direct response of limiting sward conditions to consumption of herbage (Hodgson 1990; Hodgson et al. 1994). In fact, in a concomitant set of experiments in the same experimental area in which the aim was to evaluate the vertical distribution of morphological components in sward herbage mass and the patterns of defoliation of individual leaves and tillers, it was demonstrated that the top 0.50 of sward canopy comprised mainly leaf lamina, regardless of management height, and that defoliation severity corresponded to 0.67 of the leaf lamina length for all leaf categories, regardless of defoliation frequency. The results indicated that animals were exploiting only the top third of the sward, a condition that would correspond to potential grazing strata of $33,67,100$ and $133 \mathrm{~mm}$ for swards maintained at 100, 200, 300 and $400 \mathrm{~mm}$, respectively (Da Silva \& Nascimento 2007). According to Hodgson et al. (1994), grazing horizons shorter than $100 \mathrm{~mm}$ correspond to a serious restriction of bite formation, resulting in a significant reduction of BM despite the high proportion of leaf in the herbage consumed. Animals did increase their BR ( 46.3 and 17.5 bites/min on swards managed at 100 and $400 \mathrm{~mm}$, respectively) in order to compensate for the smaller BM and, for the $100 \mathrm{~mm}$ swards, they also increased GT (684 and 630 min on swards managed at 100 and 400 mm, respectively). However, HI remained lower, probably because intake per bite normally has a larger influence on daily $\mathrm{HI}$ than BR (Hodgson 1985; Spalinger \& Hobbs 1992; Parsons et al. 1994; Cosgrove 1997; Illius 1997; Baumont et al. 2004). Larger values of daily intake and BM were associated with lower BR and GT, indicating a similar pattern of response to what has already been described for temperate grass forage species (Gordon 2000; Laca \& Lemaire 2000; Wade \& Carvalho 2000). Similar results have been reported by Difante et al. (2010) for Tanzania guinea grass (Panicum maximum Jacq. cvar Tanzania), highlighting consistency and indicating that there are more similarities than differences between tropical and temperate forage grass species. The higher weight gain per animal on swards managed at 300 and $400 \mathrm{~mm}$ was associated with lower SR, and a larger weight gain/ha was recorded on swards managed at 300 and $400 \mathrm{~mm}(569$ and $571 \mathrm{~kg} / \mathrm{ha}$, respectively). 


\section{CONCLUSIONS}

On marandu palisade grass, plant and animal responses are determined by SSH and influenced by season of the year. During the pasture growing season (late spring and summer), rates of herbage accumulation are relatively stable on swards maintained at 200-40 mm, with little difference in nutritive value. Within that range of sward conditions, differences in animal performance are basically a consequence of differences in $\mathrm{HI}$, since larger weight gains were recorded on tall swards, associated with large BM and intake rate. The results indicate large flexibility of grazing management of this forage grass species under continuous stocking and highlight the importance of providing adequate grazing conditions to allow efficient grazing. Sward height is an easy and efficient way of implementing and monitoring such management practices, and could be used as management guide in field conditions.

\section{REFERENCES}

ANDRADE, R. P. (2001). Pasture seed production technology in Brazil. In Proceedings of the 19th International Grassland Congress (Eds J. A. Gomide, W. R. S. Mattos \& S. C. Da Silva), pp. 129-132. São Pedro, SP, Brazil: Brazilian Society of Animal Husbandry.

Association of Official Agricultural Chemists - AOAC (1990). Official Methods of Analysis of the Association of Official Analytical Chemists. Washington, DC: Association of Official Analytical Chemists.

Baumont, R., Cohen-Salmon, D., Prache, S. \& Sauvant, D. (2004). A mechanistic model of intake and grazing behaviour in sheep integrating sward architecture and animal decisions. Animal Feed Science and Technology 112, 5-28.

Benvenutti, M. A., Gordon, I. J. \& Poppl, D. P. (2006). The effect of the density and physical properties of grass stems on the foraging behaviour and instantaneous intake rate by cattle grazing an artificial reproductive tropical sward. Grass and Forage Science 61, 272-281.

BiRCHAM, J. S. \& HODGSON, J. (1983). The influence of sward condition on rates of herbage growth and senescence in mixed swards under continuous stocking management. Grass and Forage Science 38, 323-331.

Braga, G. J., Pedreira, C. G. S., Herling, V. R., Luz, P. H. C.; Marchesin, W. A. \& Macedo, F. B. (2009). Quantifying herbage mass on rotationally stocked palisadegrass pastures using indirect methods. Scientia Agricola 66, 127-131.

BURns, J. C., POND, K. R. \& FISHER, P. S. (1994). Measurement of forage intake. In Forage Quality, Evaluation and Utilization (Ed. G. C. Fahey Jr), pp. 494-532. Madison, WI: ASA, CSSA \& SSSA.
Carnevall, R. A., Da Silva, S.C., Carvalho, C. A. B., SBrisia, A. F., Fagundes, J.L., Pinto, L. F.M. \& PedreiRa, C.G.S. (2001a) Desempenho de ovinos e respostas de pastagens de Coastcross submetidas a regimes de desfolha sob lotação contínua. Pesquisa Agropecuária Brasileira 36, 919-927.

Carnevalli, R. A., Da Silva, S. C., Fagundes, F. L., Sbrissia, A. F., Carvalmo, C. A. B., Pinto, L.F.M. \& Pedreira, C.G.S. (2001b) Desempenho de ovinos e respostas de pastagens de Tifton 85 (Cynodon spp.) sob lotação contínua. Scientia Agricola 58, 7-15.

Carvalho, P. C. F., Ribeiro Fllho, H. M. N., Poli, C. H. E. C., Moraes, A. \& Delagarde, R. (2001). Importância da estrutura da pastagem na ingestão e seleção de dietas pelo animal em pastejo. In Produção Animal na visão dos Brasileiros (Eds W. R. S. Mattos, V. P. De Faria, S. C. Da Silva, L. G. Nussio \& J. C. Moura), pp. 853-871. São Paulo, Brazil: Fundação de Estudos Agrários Luiz de Queiroz.

CosGrove, G. P. (1997). Grazing behavior and forage intake. In: Simpósio Internacional sobre produção animal em pastejo. (Ed J. A. Gomide), pp. 59-80. Viçosa, Brazil: UFV.

Da Silva, S. C. \& CarValHo, P. C. F. (2005). Foraging behavior and herbage intake in the favorable tropics/subtropics. In Grassland: a Global Resource (Ed D. A. McGilloway), pp. 81-96. Wageningen: Wageningen Academic Publishers.

Da Silva, S. C. \& Nascimento, D. Jr (2007). Avanços na pesquisa com plantas forrageiras tropicais em pastagens: características morfofisiológicas e manejo do pastejo. Revista Brasileira de Zootecnia 36, 121-138.

Davies, D. A., Fothergill, M. \& Morgan, C.T. (1993). Assessment of contrasting perennial ryegrasses with and white clover, under continuous stocking in the uplands. 5 - Herbage production, quality and intake in years 4-6. Grass and Forage Science 48, 213-222.

Difante, G.S., Euclides, V.P. B., Nascimento, D. Jr, DA Silva, S. C., Barbosa, R. A. \& Torres, R. A. A. Jr (2010). Desempenho e conversão alimentar de novilhos de corte em capim-tanzânia submetido a duas intensidades de pastejo sob lotação rotativa. Revista Brasileira de Zootecnia 39, 33-41.

Euclides, V.P. B., Macedo, M.C.M., Valle, C. B., Difante, G. S., Barbosa, R. A. \& Cacere, E. R. (2009). Valor nutritivo da forragem e produção animal em pastagens de Brachiaria brizantha. Pesquisa Agropecuária Brasileira 44, 98-106.

Fagundes, J. L., Da Silva, S. C., Pedreira, C. G. S., Sbrissia, A. F., Carnevalli, R. A., Carvalho, C.A.B. \& Pinto, L. F.M. (1999). Intensidades de pastejo e a composição morfológica de pastos de Cynodon spp. Scientia Agricola 56, 897-908.

Flores, R. S., Euclides, V. P. B., Abrão, M. P. C., Galbeiro, S., Difante, G.S. \& Barbosa, R. A. (2008). Desempenho animal, produção de forragem e características estruturais dos capins marandu e xaraés submetidos a intensidades de pastejo. Revista Brasileira de Zootecnia 37, 13551365.

GifFord, R. M. \& Marshall, C. (1973). Photosynthesis and assimilate distribution in Lolium multiflorum Lam. following differential tiller defoliation. Australian Journal of Biological Science 26, 517-526. 
Gordon, I. J. (2000). Plant-animal interactions in complex communities: from mechanism to modelling. In Grassland Ecophysiology and Grazing Ecology (Eds J. Hodgson, G. Lemaire, A. Moraes, P.C. F. Carvalho \& C. Nabinger), pp. 191-207. Wallingford, Oxon, UK: CAB International.

Hernandez-Garay, A., Matthew, C. \& Hodgson, J. (2000). The influence of defoliation height on dry-matter partitioning and $\mathrm{CO}_{2}$ exchange of perennial ryegrass miniature swards. Grass and Forage Science 55, 372-376.

Hodgson, J. (1982). Ingestive behaviour. In Herbage Intake Handbook (Ed J. D. Leaver), pp. 113-138. Hurley, Berks, UK: British Grassland Society.

Hodgson, J. (1985). The significance of sward characteristics in the management of temperate sown pastures. In Proceedings of the 15th International Grassland Congress (Eds T. Okubo \& M. Shiyomi), pp. 63-66. Nishinasuno, Tochini-ken, Japan: Japanese Society of Grassland Science.

Hodgson, J. \& DA Silva, S. C. (2002). Options in tropical pasture management. In Anais de Simpósios da 39th Reunião Anual da Sociedade Brasileira de Zootecnia (Eds A. M. V. Batista, S. B. P. Barbosa, M. V. F. Santos \& L. M. C. Ferreira), pp. 180-202. Recife, Brazil: Sociedade Brasileira de Zootecnia.

Hodgson, J., Clark, D. A. \& Mitchell, R. J. (1994). Foraging behavior in grazing animals and its impact on plant communities. In Forage Quality, Evaluation and Utilization (Ed. G. C. Fahey Jr), pp. 796-827. Madison, WI, USA: ASA, CSSA \& SSSA.

Hodgson, J.G. (1990) Grazing Management: Science into Practice. Essex, UK: Longman Scientific \& Technical.

Holden, L. A. (1999). Comparison of methods of in vitro dry matter digestibility for ten feeds. Journal of Dairy Science 82, 1791-1794.

Instituto Brasileiro De Geografia E Estatística - IBGE (2009). Censo Agropecuário 2006: Brasil, Regiões e Unidades da Federação. Rio de Janeiro, Brazil: IBGE.

ILlıus, A. W. (1997). Advances and retreats in specifying the constraints on intake in grazing ruminants. In Proceedings of the 18th International Grassland Congress (Eds J. G. Buchanan-Smith, L.D. Bailey \& P. McCaughey), pp. 39-44. Winnipeg, Canada: Canadian Forage Council, Canadian Society of Agronomy and Canadian Society of Animal Science.

Jank, L., Valle, C. B. do \& Resende, R. M. S. (2005). Grass and forage plant improvement in the tropics and sub-tropics. In Grassland: a Global Resource (Ed. D. A. Gilloway), pp. 69-80. The Netherlands: Wageningen Academic Publishers.

LACA, E. A. \& Lemaire, G. (2000). Measuring sward structure. In Field and Laboratory Methods for Grassland and Animal Production Research (Eds L. Mannetje \& R. M. Jones), pp. 103-121. Wallingford, UK: CABI.

Lemaire, G., Da Silva, S.C., Agnusdel, M., Wade, M. \& Hodgson, J. (2009). Interactions between leaf lifespan and defoliation frequency in temperate and tropical pastures: a review. Grass and Forage Science 64, 341-353.
Littel, R. C., Pendergast, J. \& Natarajan, R. (2000). Modeling covariance structure in the analysis of repeated measures data. Statistics in Medicine 19, 1753-1819.

Mesquita, P., Da Silva, S. C., Paiva, A. J., Caminha, F. O., Pereira, L. E. T., Guarda, V. D. \& Nascimento, D. Jr (2010). Structural characteristics of marandu palisadegrass swards subjected to continuous stocking and contrasting rhythms of growth. Scientia Agricola 67, 23-30.

Oliveira, D. E., Medeiros, S. R., Tedeschi, L. O., Aroeira, L. J. M. \& DA SILVA, S.C. (2007). Estimating forage intake of lactating dual-purpose cows using chromium oxide and n-alkanes techniques as external markers. Scientia Agricola 64, 103-110.

Parsons, A. F., Johnson, I. R. \& Harvey, A. (1988). Use of a model to optimize the interaction between frequency and severity of intermittent defoliation and to provide a fundamental comparison of the continuous and intermittent defoliation of grass. Grass and Forage Science 43, 46-59.

Parsons, A. J., Thornley, H. M., Newman, J. \& Penning, P. D. (1994). A mechanistic model of some physical determinants of intake rate and diet selection in a two-species temperate grassland sward. Functional Ecology 8, 187204.

Pedreira, J. V.S. \& Mattos, B. B. (1981). Crescimento estacional de vinte e cinco espécies e variedades de capins. Boletim de Industria Animal 38, 117-143.

Pinto, L.F.M., Da Silva, S.C., Sbrissia, A. F., Carvalho, C.A. B., Carnevalli, R. A., Fagundes, J. L. \& Pedreira, C. G. S. (2001). Dinâmica do acúmulo de matéria seca em pastagens de Tifton 85 sob pastejo. Scientia Agricola 58, 439-447.

Sbrissia, A. F., Da Silva, S. C., Sarmento, D. O. L., Molan, L. K., Andrade, F. M. E., Gonçalves, A. C. \& Lupinacci, A. V. (2010). Tillering dynamics in palisadegrass swards continuously stocked by cattle. Plant Ecology 206, 349359.

Sollenberger, L. E. \& Cherney, D. J.R. (1995). Evaluating forage production and quality. In Forages, vol. 2: The Science Grassland Agriculture (Eds R. F. Barnes, D. A. Miller \& C. J. Nelson), pp. 97-110. Ames, IA: lowa State University Press.

Spalinger, D. E. \& HobBs, N.T. (1992). Mechanisms of foraging in mammalian herbivores, new models of functional response. American Naturalist 140, 325-348.

StoввS, T. H. (1973). The effect of plant structure on the intake of tropical pastures. I. Variation in the bite size of grazing cattle. Australian Journal of Agricultural Research 24, 809819.

Thornthwaite, C.W. \& Mather, J.R. (1955). The Water Balance. Publications in Climatology 8. Centerton, NJ: Drexel Institute of Climatology.

van Ralı, B., Cantarella, H., Quaggio, J. A. \& Furlani, A. M. C. (1986). Recomendações de Adubação e Calagem para o Estado de São Paulo. Boletim Técnico no. 100. Campinas, Brazil: Instituto Agronômico Fundação IAC.

Van Soest, P. J., Robertson, J. B. \& Lewis, B. (1991). Methods for dietary fiber, neutral detergent fiber, and non-starch polysaccharides in relation to animal nutrition. Journal of Dairy Science 74, 3583-3597. 
Wade, M. H. \& Carvalho, P. C. F. (2000). Defoliation patterns and herbage intake on pastures. In Grassland Ecophysiology and Grazing Ecology (Eds G. Lemaire, J. Hodgson, A. de Moraes, P.C.F. Carvalho \& C. Nabinger), pp. 233-248. Wallingford, Oxon: CAB International.
Wolfinger, R. D. (1993). Covariance structure selection in general mixed models. Communications in Statistics, Simulation and Computation 22, 1079-1106.

Woledge, J. (1977). The effects of shading and cutting treatments on the photosynthetic rate of ryegrass leaves. Annals of Botany 41, 1279-1286. 